\title{
BioOne

\section{Lethal High Temperature Extremes of the Brown Marmorated Stink Bug (Hemiptera: Pentatomidae) and Efficacy of Commercial Heat Treatments for Control in Export Shipping Cargo}

\author{
Author(s): J. D. Aigner and T. P. Kuhar
}

Source: Journal of Agricultural and Urban Entomology, 32(1):1-6.

Published By: South Carolina Entomological Society

DOI: http://dx.doi.org/10.3954/1523-5475-32.1.1

URL: http://www.bioone.org/doi/full/10.3954/1523-5475-32.1.1

BioOne (www.bioone.org) is a nonprofit, online aggregation of core research in the biological, ecological, and environmental sciences. BioOne provides a sustainable online platform for over 170 journals and books published by nonprofit societies, associations, museums, institutions, and presses.

Your use of this PDF, the BioOne Web site, and all posted and associated content indicates your acceptance of BioOne's Terms of Use, available at www.bioone.org/page/terms of use.

Usage of BioOne content is strictly limited to personal, educational, and non-commercial use. Commercial inquiries or rights and permissions requests should be directed to the individual publisher as copyright holder.

BioOne sees sustainable scholarly publishing as an inherently collaborative enterprise connecting authors, nonprofit publishers, academic institutions, research libraries, and research funders in the common goal of maximizing access to critical research. 


\title{
Lethal High Temperature Extremes of the Brown Marmorated Stink Bug (Hemiptera: Pentatomidae) and Efficacy of Commercial Heat Treatments for Control in Export Shipping Cargo ${ }^{1}$
}

\author{
J. D. Aigner ${ }^{2}$ and T. P. Kuhar ${ }^{2,3}$
}

J. Agric. Urban Entomol. 32: 1-6 (2016)

Since its accidental introduction into the U.S.A. in the mid-1990s, the brown marmorated stink bug, Halyomorpha halys Stål (Hemiptera: Pentatomidae), has spread rapidly across North America and become an economically significant pest of tree fruits, vegetables, tree nuts, and field crops (Leskey et al. 2012, Rice et al. 2014). Consequently, there has been tremendous interest in better understanding aspects of its biology. Knowledge on the effects of temperature on the bug's biology is critical to developing ecological models (Nielsen et al. 2008), predicting range expansion (Zhu et al. 2012), and for potentially developing pest control tactics using controlled temperature (Hammond 2015). In two laboratory experiments, we determine the lethal high temperature extremes of $H$. halys and efficacy of commercial heat treatments for control of the bug in export shipping cargo.

Experiments were conducted in 2014 and 2015 in a laboratory at Virginia Tech in Blacksburg, VA to determine the lethal high temperature of the brown marmorated stink bug. All insects used in experiments were obtained from a laboratory colony maintained in mesh cages $(30.48 \mathrm{~cm} \times 30.48 \mathrm{~cm} \times 30.48 \mathrm{~cm})$ (BioQuip, Rancho Dominquez, CA) at $23^{\circ} \mathrm{C}$, 12 -h photoperiod, and $50 \%$ relative humidity. Bugs were fed fresh seeds from green beans, Phaseolus vulgaris L. (Fabaceae), and sunflower, Helianthus annuus L. (Asteraceae), and they were supplied with water through a wick. The colony was continuously supplemented with field-collected $H$. halys from trees and crops in Virginia during the summer months or from manmade structures in the fall and winter of each year. Adults of both sexes were haphazardly selected from the colony and placed in groups of ten in 9-cm glass Petri dishes (Corning, Inc., Corning, NY). These groups of bugs were placed in an incubator (Fisher Scientific Thermo Incubator 537D, Fisher Scientific, Waltham, MA) at different temperature-time intervals. Bugs were exposed for $4 \mathrm{~h}$ at the following temperatures: 35, 38, 40, 42, and $45^{\circ} \mathrm{C}$. Additionally, bugs were exposed for 15-min and 1-h intervals at 40,45 , and $50^{\circ} \mathrm{C}$. Mortality was assessed at $1 \mathrm{~h}$ and $24 \mathrm{~h}$ after exposure. Bugs unable to walk

\footnotetext{
${ }^{1}$ Accepted for publication 8 December 2015.

${ }^{2}$ Virginia Polytechnic Institute and State University, Department of Entomology, Blacksburg, Virginia 24061 U.S.A.

${ }^{3}$ Corresponding author: tkuhar@vt.edu
} 


\section{Table 1. Average mortality of $\boldsymbol{H}$. halys adults following exposure for different times and temperatures in an incubator located at Virginia Tech, Blacksburg, VA.}

\begin{tabular}{lccr}
\hline \hline & \multicolumn{3}{c}{$\%$ mortality $(\text { mean } \pm \mathrm{SE})^{\mathrm{a}}$} \\
\cline { 2 - 4 } Temp. $\left({ }^{\circ} \mathrm{C}\right)$ & 15 -min exposure ${ }^{\mathrm{b}}$ & $1-\mathrm{h}$ exposure & 4 -h exposure \\
\hline 35 & - & - & $5.0 \pm 1.4 \mathrm{c}$ \\
38 & - & - & $11.7 \pm 1.9 \mathrm{c}$ \\
40 & $0.0 \pm 0.0 \mathrm{~b}$ & $0.0 \pm 0.0 \mathrm{~b}$ & $38.3 \pm 3.7 \mathrm{~b}$ \\
42 & - & - & $91.3 \pm 2.2 \mathrm{a}$ \\
45 & $22.5 \pm 19.3 \mathrm{~b}$ & $100.0 \pm 0.0 \mathrm{a}$ & $100.0 \pm 0.0 \mathrm{a}$ \\
50 & $100.0 \pm 0.0 \mathrm{a}$ & $100.0 \pm 0.0 \mathrm{a}$ & - \\
\hline
\end{tabular}

aThere were four replications, and more than 50 bugs per temperature-time treatment.

${ }^{\mathrm{b}}$ Means within columns followed by the same letter are not significantly different (ANOVA, LSD test, $\alpha=$ $0.05)$.

properly and right themselves after being turned over on their backs were considered lethally injured from the heat exposure and were recorded as dead. Each time and temperature combination was replicated at least four times. Percentage mortality at $24 \mathrm{~h}$ after exposure were analyzed using analysis of variance (ANOVA) (JMP version 10.0; SAS Institute 2012). Means were separated using Fisher's Protected Least Significant Difference (LSD) at $\alpha=0.05$.

Temperature had a significant effect on bug mortality for the 15-min $(F=$ 10.88; $\mathrm{df}=2,9 ; P<0.004), 1$-h $(F=80,000 ; \mathrm{df}=2,9 ; P<0.0001)$, and 4 -h exposure times $(F=50.57 ; \mathrm{df}=4,25 ; P<0.0001)$. All $H$. halys adults that were exposed to $50^{\circ} \mathrm{C}$ for $\geq 15 \mathrm{~min}$ or to $45^{\circ} \mathrm{C}$ for $\geq 1 \mathrm{~h}$ were killed (Table 1 ). The $H$. halys adults exposed to $35^{\circ}, 38^{\circ}, 40^{\circ}, 42^{\circ}$, and $45^{\circ} \mathrm{C}$ for $4 \mathrm{~h}$ had an observed mean mortality of $5,12,38,91$, and $100 \%$, respectively. Mortality at 42 and $45^{\circ} \mathrm{C}$ was significantly higher than it was at the other temperatures, and mortality at $40^{\circ} \mathrm{C}$ was higher than it was at either $38^{\circ} \mathrm{C}$ or $35^{\circ} \mathrm{C}$.

A second study was conducted to evaluate the potential of heat treatments for control of live $H$. halys in export cargo. In 2015, a heat-treatment facility at the Port of Savannah, GA, USA was constructed by Willenius Wilhelmsen Logistics (WWL, Lysaker, Norway) to create a usable heated space approximately $6.1 \mathrm{~m} \times 12.2 \mathrm{~m} \times 3 \mathrm{~m}$ (Figure 1a). The interior of the facility was coated with a series of spray foam insulation and 5 -cm wide foam board insulation to reduce heat loss. One end of the facility allowed for vehicles to enter through a standard exterior grade metal garage door, while the opposite end housed three 500,000 BTU propane heaters (PEST-HEAT, Aston, PA) (Figure 1b) that allowed the heat to move throughout the space. These heaters were supplied by a 3785-liter propane tank located in the rear of the facility. Current capabilities of this space allow for treatment of up to four standard-sized passenger vehicles at one time.

For our studies at the Port of Savannah, $H$. halys field mortality was assessed using a seven-passenger 2003 Chevrolet Astro Extended Wagon. This vehicle had a 4.6-L V6 CPI engine. The same vehicle was used for all experiments. Previous 


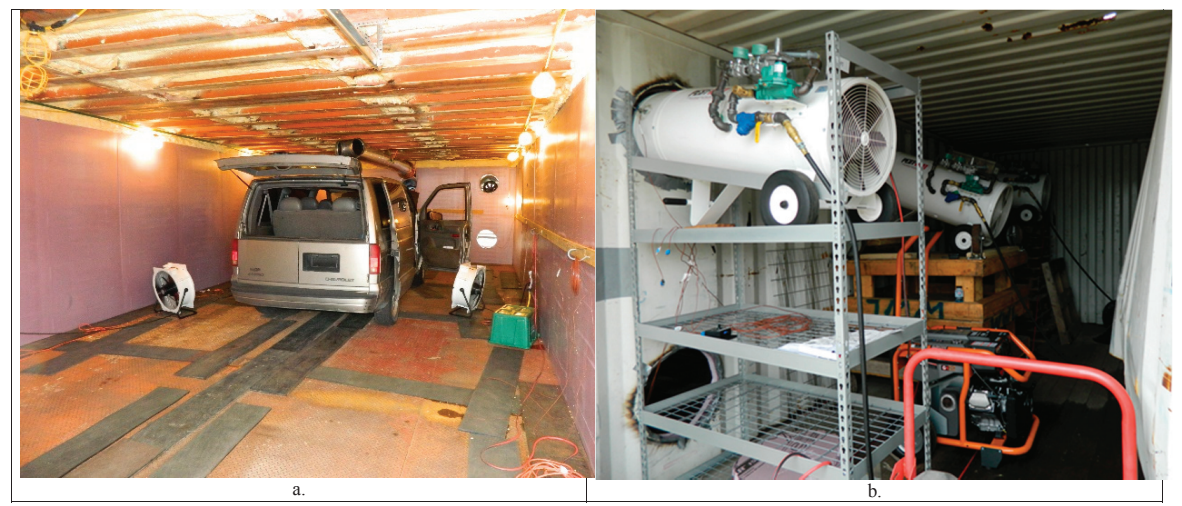

Fig. 1. (a) Vehicle used for experiments parked inside a container heat treatment facility constructed by Willenius Wilhelmsen Logistics (WWL), and (b) the 500,000 BTU propane heaters used to generate lethal temperature extremes greater than $60^{\circ} \mathrm{C}$ for heat treatment of vehicles.

testing by WWL identified the engine compartment, under the driver or passenger seats and interior areas that house the spare tire to be the coldest spots during the heat treatment. The test vehicle did not have an interior spare tire compartment; therefore, we were only able to test for bug survival in the engine compartment and under the seat.

The vehicle was parked in the heat treatment facility and subjected to targeted heat treatments of $40^{\circ}, 50^{\circ}$, and $60^{\circ} \mathrm{C}$. Ten adults (collected near Sharpsburg, MD the week prior to testing) were placed in 1-liter mesh bags (Figure 2) and then placed in the engine compartment and under the driver's seat for 15 min once the minimum temperatures in these areas reached the target temperatures. After reaching the minimum target, temperatures were monitored at each location every $60 \mathrm{~s}$ for 15 min using a hard-wired thermocouple integrated to a BlueTherm Duo system (Thermoworks, Lindon, UT) integrated with the BlueTherm Pro software (Thermoworks, Lindon, UT) for tablets. Stink bugs were removed and assessed for mortality at 0,1 , and $24 \mathrm{~h}$ after the heat treatment. Each temperature treatment was replicated eight times and each replication had a control group of ten $H$. halys that were held at ambient temperature with a mean of $16^{\circ} \mathrm{C}$. As with the previous experiment, percentage mortality at $24 \mathrm{~h}$ after exposure were analyzed using ANOVA (JMP version 10.0; SAS Institute 2012) and means were separated using Fisher's Protected LSD.

In the second study, temperatures recorded from under the driver's seat were about 2 to $3^{\circ} \mathrm{C}$ cooler than those recorded in the engine compartment, but both were at least at the minimal targeted temperature generated from the heat treatment (Table 2). Temperature had a significant effect on bug mortality $(F=$ $21,600 ; \mathrm{df}=2,21 ; P<0.0001)$. Targeted heat treatment exposures for $15 \mathrm{~min}$ at either 50 or $60^{\circ} \mathrm{C}$ resulted in $100 \%$ mortality of the adults tested, regardless of location in the vehicle. Heat treatments at $40^{\circ} \mathrm{C}$ resulted in very low mortality of adults. All $H$. halys held under ambient conditions during this study resulted in $0 \%$ mortality. 


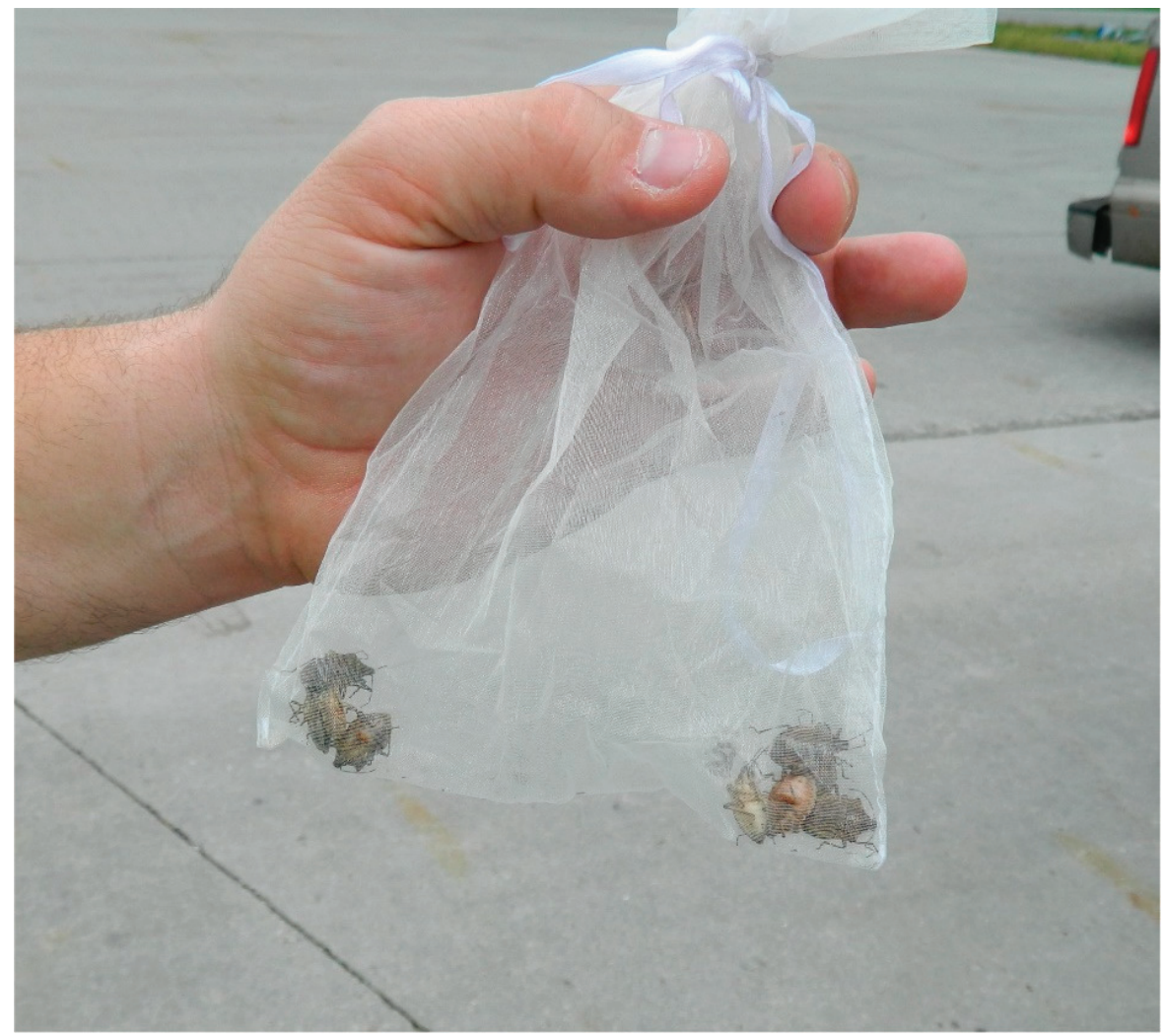

Fig. 2. Dead brown marmorated stink bugs in a mesh bag after removal from under the seat of a vehicle exposed to heat treatments at the Port of Savannah, GA.

Table 2. Targeted temperatures, actual measured temperatures, and observed mortality of $\boldsymbol{H}$. halys adults after 15 min exposures to heat treatments applied to a vehicles at the Port of Georgia, Savannah, GA in 2015.

\begin{tabular}{|c|c|c|c|c|}
\hline \multirow[b]{2}{*}{$\begin{array}{l}\text { Target } \\
\text { temp. }\left({ }^{\circ} \mathrm{C}\right)\end{array}$} & \multicolumn{2}{|c|}{$\begin{array}{l}\text { Actual measured temp. } \\
\quad\left(\text { mean }{ }^{\circ} \mathrm{C} \pm \mathrm{SE}\right)\end{array}$} & \multicolumn{2}{|c|}{$\begin{array}{c}\% \text { mortality } \\
(\text { mean } \pm \mathrm{SE})^{\mathrm{a}}\end{array}$} \\
\hline & $\begin{array}{c}\text { Under driver's } \\
\text { seat }\end{array}$ & $\begin{array}{c}\text { Engine } \\
\text { compartment }\end{array}$ & $\begin{array}{l}\text { Under driver's } \\
\text { seat }^{\mathrm{b}}\end{array}$ & $\begin{array}{c}\text { Engine } \\
\text { compartment }^{\mathrm{b}}\end{array}$ \\
\hline 40 & $39.1 \pm 0.2$ & $42.2 \pm 0.3$ & $2.5 \pm 2.5 \mathrm{~b}$ & $17.5 \pm 17.5 \mathrm{~b}$ \\
\hline 50 & $50.9 \pm 0.1$ & $54.2 \pm 0.1$ & $100.0 \pm 0.0 \mathrm{a}$ & $100.0 \pm 0.0 \mathrm{a}$ \\
\hline 60 & $65.0 \pm 0.7$ & $67.1 \pm 0.8$ & $100.0 \pm 0.0 \mathrm{a}$ & $100.0 \pm 0.0 \mathrm{a}$ \\
\hline
\end{tabular}

${ }^{\text {a } O b s e r v e d ~ f o r ~} 24 \mathrm{~h}$ after 15 min of exposure to temperatures.

${ }^{\mathrm{b}}$ Means within columns followed by the same letter are not significantly different (ANOVA, LSD test, $\alpha=0.05$ ). 
Most insects cannot survive exposure to extreme heat $\left(>50^{\circ} \mathrm{C}\right)$ for even brief durations (Hammond 2015). High temperatures disrupt the function of proteins, metabolic enzymes, and the respiratory and endocrine systems, all of which can lead to insect mortality (Neven 2000). Our results showed that $H$. halys adults are killed after exposure for $15 \mathrm{~min}$ to $50^{\circ} \mathrm{C}$ or $1 \mathrm{~h}$ or more exposure to $45^{\circ} \mathrm{C}$. These lethal high temperature levels are consistent with many other insects (Hammond 2015). According to Burkes et al. (2000) and Fields \& White (2002), most stored-product insect pests (coleopterans and lepidopterans) are effectively controlled under the following time-temperature combinations: $24 \mathrm{~h}$ at $40^{\circ} \mathrm{C}, 12 \mathrm{~h}$ at $45^{\circ} \mathrm{C}, 5 \mathrm{~min}$ at $50^{\circ} \mathrm{C}, 1 \mathrm{~min}$ at $55^{\circ} \mathrm{C}$, and $30 \mathrm{~s}$ at $60^{\circ} \mathrm{C}$. Thus, $H$. halys appear to follow a similar pattern of mortality.

These results may have implications on heat treatment control guidelines (restrictions) for shipping cargo. For instance, recent restrictions were placed on the shipping of potential $H$. halys-infested cargo from the U.S. to other countries. During periods of restriction, if vehicles cannot be fumigated prior to transport, they are currently required to be heat-treated at $60^{\circ} \mathrm{C}$ for $20 \mathrm{~min}$ (restrictions set by New Zealand) (Thompson 2014) or 30 min (restrictions set by Australia) (Australian Government 2015) prior to boarding cargo ships. This heat treatment regime has been found to be quite difficult to achieve in an efficient manner for treating large cargo such as multiple vehicles because of the difficulty in constantly maintaining an enclosure at $60^{\circ} \mathrm{C}$. Consequently, fumigants have been the primary choice for treatment of stink bugs in export goods mostly because of efficiency (Thompson 2014). However, heat treatments are often less expensive, and do not involve the use of toxic gases, such as phosphine $\left(\mathrm{PH}_{3}\right)$ or methyl bromide, which have numerous environmental and human safety issues (Hammond 2015). Based on our research, heat treating export cargo at $50^{\circ} \mathrm{C}$ rather than $60^{\circ} \mathrm{C}$ would dramatically improve the efficiency of the process without losing insect control efficacy. Based on our estimates and field testing with WWL at the shipping port in Savannah, GA, such a switch would basically cut the time of heat treatment in half, and thus double the amount of vehicles that could be treated in a day. More efficient heat treatment controls could help to reduce our reliance on fumigation as a means of insect control in exports.

\section{Acknowledgements}

The authors would like to thank Ashley Lohr and Jamie Hogue for their invaluable assistance with the implementation of this study. We would like to extend our thanks to Craig Kessler of the Georgia Port Authority and Phil Hansen and Sean Lilly of Wallenius Wilhelmsen Logistics for allowing the use of their facility and their hospitality. This project was funded in part by the USDA-NIFA-SCRI Grant \# 2011-51181-30937.

\section{References Cited}

Australian Government. 2015. Brown marmorated stink bug: emergency measures for break bulk and containerised vehicles, machinery, automotive parts and tyres. Australian Government, Department of Agriculture, Canberra City, Australia. Available at: http:// www.agriculture.gov.au/SiteCollectionDocuments/biosecurity/import/general-info/ian/15/ notice-to-industry-04-2015.pdf; accessed 8 December 2015. 
Burkes, C. S., J. A. Johnson, D. E. Maier \& J. W. Heaps. 2000. Temperature, pp. 73104. In B. H. Subramanyam \& D. W. Hagstrum [Eds.], Alternatives to Pesticides in Stored-Product IPM. Kluwer Academic, Boston, MA, 437 pp.

Fields, P. G. \& N. D. G. White. 2002. Alternatives to methyl bromide treatments for stored-product and quarantine insects. Annu. Rev. Entomol. 47: 331-359.

Hammond, D. 2015. Heat treatment for insect control: developments and applications. Woodhead Publishing Series in Food Science, Technology and Nutrition: Number 241. Woodhead Publishing, Amsterdam, Netherlands, 99 pp.

Leskey, T. C., G. C. Hamilton, A. L. Nielsen, D. F. Polk, C. Rodriguez-Saona, J. C. Bergh, D. A. Herbert, T. P. Kuhar, D. Pfeiffer, G. P. Dively, C. R. R. Hooks, M. J. Raupp, P. M. Shrewsbury, G. Krawczyk, P. W. Shearer, J. Whalen, C. KoplinkaLoehr, E. Myers, D. Inkley, K. A. Hoelmer, D.-H. Lee \& S. E. Wright. 2012. Pest status of the brown marmorated stink bug, Halyomorpha halys in the USA. Outlooks Pest Manage. 23: 218-226.

Neven, L. G. 2000. Physiological responses of insects to heat. Postharvest Biol. Technol. 21: 103-111.

Nielsen, A. L., G. C. Hamilton \& D. Matadha. 2008. Developmental rate estimation and life table analysis for Halyomorpha halys (Hemiptera: Pentatomidae). Environ. Entomol. 27: 348-355.

Rice, K. B., C. J. Bergh, E. J. Bergmann, D. J. Biddinger, C. Dieckhoff, G. Dively, H. Fraser, T. Gariepy, G. Hamilton, T. Haye, A. Herbert, K. Hoelmer, C. R. Hooks, A. Jones, G. Krawczyk, T. Kuhar, H. Martinson, W. Mitchell, A. L. Nielsen, D. G. Pfeiffer, M. J. Raupp, C. Rodriguez-Saona, P. Shearer, P. Shrewsbury, P. D. Venugopal, J. Whalen, N. G. Wiman, T. C. Leskey \& J. F. Tooker. 2014. Biology, ecology, and management of brown marmorated stink bug (Hemiptera: Pentatomidae). J. Integr. Pest Manag. 5: 1-13.

SAS Institute. 2012. JMP version 10.0. SAS Institute, Cary, NC.

Thompson, P. 2014. Import health standard for vehicles, machinery and tyres. VehicleAll-V1.1. Ministry for Primary Industries, Wellington, NZ. Available at: https://mpi.govt. nz/document-vault/1189; accessed 8 December 2015.

Zhu, G., W. Bu, Y. Gao \& G. Liu. 2012. Potential geographic distribution of brown marmorated stink bug invasion (Halyomorpha halys). PLoS ONE 7(2): e31246. Available at: http://journals.plos.org/plosone/article?id=10.1371/journal.pone.0031246; accessed 8 December 2015. 